\title{
Varietal Preference of Okra Shoot and Fruit Borer, Earias vittella (Fab.) in Summer Season under Field Condition in Konkan Region of Maharashtra
}

\author{
Vinayak N. Jalgaonkar ${ }^{1 *}$, Manoj Mahla ${ }^{2}$, Kumud Naik ${ }^{3}$, \\ Anil Vyas ${ }^{2}$ and Gopal Golvankar ${ }^{3}$ \\ ${ }^{1}$ Entomologist Regional Agricultural Research Station, Karjat, Dist. Raigad - 410201 \\ (M.S.), India \\ ${ }^{2}$ Department of Entomology, Rajasthan College of Agriculture, Maharana Pratap University \\ of Agriculture and Technology, Udaipur-313001 (Rajasthan), India \\ ${ }^{3}$ Department of Entomology, College of Agriculture, Dr. BSKKV, Dapoli, Dist. \\ Ratnagiri, 415712 (M.S.), India \\ *Corresponding author
}

\section{A B S T R A C T}

Keywords

Okra, okra shoot and fruit borer, Eariasvittella, Variety preference

Article Info

Accepted:

18 October 2018 Available Online:

10 November 2018
The field experiment was conducted to study the varietal preference of okra shoot and fruit borer, Earias vittella (Fab.) under field condition in Konkan region during summer 2016 and 2017 at RARS, Karjat. There were eight varieties viz., ArkaAnamika, Akola 10, Akola Bahar, PhuleUtakarsh, GOA-5, ParbhaniKranti, Panjab, Padmini, and VarshaUpahar (as a check) were screened for their relative susceptibility to okra shoot and fruit borer under field conditions. Among the eight genotypes/varieties of okra, none of the cultivars was found to be free from pest infestation in the year 2016 and 2017. The minimum shoot damage was recorded on variety Akola bahar (12.98\%), whereas the maximum damage was recorded on Punjab Padmini $(26.81 \%)$. The per cent fruit damage revealed that the infestation fruit damage ranged from 21.29 to 36.38 per cent on different genotypes/varieties. The variety Akola 107 recorded less damage (21.29\%) to fruits as compared to rest of the other varieties.

\section{Introduction}

Several insect pests have so far been recorded to attack okra like okra shoot and fruit borer (OSFB), jassid, aphid, whitefly, and cotton leaf roller. Among these pests OSFB (Eariassp.) is considered as the most important one (Aziz et al., 2011) which causes both quantitative and qualitative losses of the okra crop (Butani and Jotwani, 1984). Earias sp. alone causes damage up to71\% (Pareek and Bhargava, 2003) whereas in general the overall pod damage is about $49 \%$ and $42 \%$ according to Kanwar and Ameta (2007) and Fletcher and Mishra (1990) respectively. Moreover, Radake and Undirwade (1981) reported that $88-100 \%$ fruits can be damaged by the okra shoot and fruit borer. The adult female okra shoot and fruit borer lays eggs individually on leaves, floral buds and on tender fruits. After hatching, small brown caterpillars bore into the top shoot and feed 
inside the shoot before fruit formation. The shoots wilt and dry results the development of side branches. When fruits become available, caterpillars bore into the fruits and feed inside as a result the infested plant bears smaller and deformed pods (Mohan et al., 1983). Knowledge on varietal preference of okra shoot and fruit borer can play a significant role in the successful okra production and its management. Unfortunately, very limited efforts were given in this regards. Considering the above situation, the present research was conducted to screen out the resistant okra variety which might be an important tool for the management of this pest.

\section{Materials and Methods}

A statistically designed field experiment was laid out in uniform sized plots in Randomized Block Design at Regional Agriculture Research Station, Karjat (M.S). The row to row and plant to plant spacing for okra was maintained at $45 \mathrm{~cm}$ and $30 \mathrm{~cm}$ respectively. Sowing of okra was done in the $1^{\text {st }}$ week of February in the year 2016 and 2017. The details of the experiment are given below.

\section{Experimental details}

Crop: Okra

Variety: Eight (8)

Design: RBD

Season: Summer season crop

Spacing: $45 \mathrm{~cm}$ X $30 \mathrm{~cm}$

Plot size: $2.5 \mathrm{~m} \mathrm{X} 3.00 \mathrm{~m}$

Eight varieties viz., ArkaAnamika, Akola 10, Akola Bahar, PhuleUtakarsh, GOA-5, ParbhaniKranti, Panjab, Padmini, and VarshaUpahar (as a check) were screened for their relative susceptibility to okra shoot and fruit borer under field conditions during summer season of year 2016 \& 2017. Each variety was grown in a gross plot of $2.5 \mathrm{X}$ $3.00 \mathrm{~m}$ with three replications and $45 \times 30 \mathrm{~cm}$ spacing at Regional Agriculture Research Station, Karjat (M.S). All the recommended agronomical practices were adopted for raising the crop. The plot of these varieties was kept unsprayed with any insecticide throughout the crop season.

\section{Method of recording observations}

\section{Shoot and fruit borer, Eariasvittella (Fabricius)}

The observations on shoot infestation and flower bud infestation were recorded from five randomly selected plants from each plot. There was no shoot infestation and flower bud infestation was minor. The observations on fruit infestation were recorded from five randomly selected plants from each plot. Total number of fruits, healthy fruits and infested fruits were recorded from five randomly selected plants from each treatment. The per cent infestation was worked out on the basis of healthy and infested fruits on number basis. The data was converted into per cent infested fruit and analysed statistically.

\section{Results and Discussion}

\section{Screening of different okra germplasm against okra shoot and fruit borer}

Results of the field experiment conducted during summer season of 2016 and 2017 at Regional Agricultural Research Station, Karjat (Maharashtra) to screen different okra germplasm reaction against major arthropod pests are mentioned below:

\section{Summer season 2016}

\section{Shoot damage}

The result was pertaining in Table 1 . The data on mean shoot damage recorded from different genotypes/varieties of okra revealed 
that, among nine genotypes/varieties of okra, none of the cultivars was found to be free from the infestation of shoot damage. The percent shoot damage by this pest varied from 12.98 to 26.81 percent. It indicates the varying response of all the varieties/genotypes to shoot damage.

The minimum shoot damage was recorded on variety Akola Bahar (12.98\%), whereas the maximum damage was recorded on Punjab Padmini (26.81\%). The Cultivars viz., PhuleUtkarsha, VarshaUpahar, GOA -5, ArkaAnamika, Akola 107, and ParbhaniKranti, recorded 15.89, 19.85, 22.00, $22.51,22.95$ and 24.37 percent damage respectively.

\section{Fruit damage}

A close perusal of the data on percent fruit damagewas pertaining in Table 1 and revealed that the infestation of fruit damage ranged from 24.42 to 36.38 percent on different genotypes/varieties. The variety Akola Bahar recorded less damage $(24.42 \%)$ to fruits as compared to rest of the other varieties. The maximum fruit damage was recorded in the variety ParbhaniKranti (36.38\%). The Cultivars viz., PhuleUtkarsha, VarshaUpahar, Akola 107, Punjab Padmini, GOA -5 and ArkaAnamika recorded 27.64, 28.59, 31.86, 32.82 and 34.57 percent damage respectively. Among eight genotypes/varieties of okra none of the cultivars was found to be free from the infestation of fruit damage.

\section{Summer season 2017}

\section{Shoot damage}

The result was pertaining in Table 2. The data on mean shoot damage recorded from different genotypes/varieties of okra revealed that, among nine genotypes/varieties of okra, none of the cultivars was found to be free from the infestation of shoot damage. The percent shoot damage varied from 16.75 to 24.54 percent. It indicates the varying response of all the varieties/genotypes to shoot damage.

The minimum shoot damage was recorded on variety Akola Bahar (16.75\%), whereas the maximum damage was recorded on Punjab Padmini (26.81\%). The Cultivars viz., PhuleUtkarsha, VarshaUpahar, GOA -5, ArkaAnamika, Akola 107, and ParbhaniKranti, recorded 17.31, 18.14, 19.96, 20.26, 20.90 and 21.05 percent damage respectively.

\section{Fruit damage}

A close perusal of the data on percent fruit damage was pertaining in Table 2 and revealed that the infestation of fruit damage ranged from 21.29 to 31.59 percent on different genotypes/varieties. The variety Akola 107 recorded less damage $(21.29 \%)$ to fruits as compared to rest of the other varieties.

The maximum fruit damage was recorded in the variety GOA- 5 (31.59\%). The Cultivars viz., ArkaAnamika, PhuleUtkarsha, ParabhaniKranti, Punjab Padmini, Akola bahar and VarshaUpahar recorded 31.01, 29.76, 29.43, 29.32, 27.81 and 26.20 percent damage respectively. Among eight genotypes/varieties of okra none of the cultivars was found to be free from the infestation of fruit damage.

These findings are in close conformity with the findings of Banger et al., (2012), reported that, out of 10 varieties screened, the variety AOL 05-1, Gujarat Okra-2 AOL 08-2 were least susceptible for fruit borer. Gonde et al., (2012) reported that the lowest infestation on number basis was recorded in EMS 8-1 followed by Punjab Padmini and VRO 3. 
Table.1 Screening of different okra germplasm against Shoot and fruit borer,

Earias vittella (Fab) during 2016

\begin{tabular}{|c|c|c|c|}
\hline \multirow[t]{2}{*}{ Sr. No. } & \multirow[t]{2}{*}{ Genotypes/varieties } & \multicolumn{2}{|c|}{ Mean damage percentage } \\
\hline & & Shoot damage (\%) & Fruit damage (\%) \\
\hline 1 & $\mathrm{~T}_{1}=$ VarshaUpahar & $\begin{array}{c}19.85 \\
(26.42)\end{array}$ & $\begin{array}{c}28.59 \\
(32.27)\end{array}$ \\
\hline 2 & $\mathrm{~T}_{2}=$ Akola Bahar & $\begin{array}{l}12.98 \\
(21.05)\end{array}$ & $\begin{array}{c}24.42 \\
(29.60)\end{array}$ \\
\hline 3 & $\mathrm{~T}_{3}=$ PhuleUtakarsh & $\begin{array}{l}15.89 \\
(23.42)\end{array}$ & $\begin{array}{l}27.64 \\
(31.69)\end{array}$ \\
\hline 4 & $\mathrm{~T}_{4}=\mathrm{GOA}-5$ & $\begin{array}{l}22.00 \\
(27.97)\end{array}$ & $\begin{array}{c}34.57 \\
(35.97)\end{array}$ \\
\hline 5 & $\mathrm{~T}_{5}=$ ArkaAnamika & $\begin{array}{c}22.51 \\
(28.32)\end{array}$ & $\begin{array}{c}33.02 \\
(35.06)\end{array}$ \\
\hline 6 & $\mathrm{~T}_{6}=$ Punjab Padmini & $\begin{array}{l}26.81 \\
(31.18)\end{array}$ & $\begin{array}{l}32.82 \\
(34.94)\end{array}$ \\
\hline 7 & $\mathrm{~T}_{7}=$ ParbhaniKarnti & $\begin{array}{l}24.37 \\
(29.53)\end{array}$ & $\begin{array}{l}36.38 \\
(37.05)\end{array}$ \\
\hline 8 & $\mathrm{~T}_{8}=$ Akola 107 & $\begin{array}{l}22.95 \\
(28.59)\end{array}$ & $\begin{array}{l}31.86 \\
(34.33)\end{array}$ \\
\hline & Mean & $\begin{array}{c}20.92 \\
(27.06)\end{array}$ & $\begin{array}{l}31.16 \\
(33.86)\end{array}$ \\
\hline & SE & 0.08 & 0.23 \\
\hline & $\mathrm{CD}$ & 0.24 & 0.70 \\
\hline
\end{tabular}

Table.2 Screening of different okra germplasm against Shoot and fruit borer, Eariasvittella (Fab) during 2017

\begin{tabular}{|c|c|c|c|}
\hline \multirow[t]{2}{*}{ Sr. No. } & \multirow[t]{2}{*}{ Genotypes/varieties } & \multicolumn{2}{|c|}{ Mean damage percentage } \\
\hline & & Shoot damage (\%) & Fruit damage (\%) \\
\hline 1 & $\mathrm{~T}_{1}=$ VarshaUpahar & $\begin{array}{c}18.14 \\
(25.18)\end{array}$ & $\begin{array}{c}26.20 \\
(30.79)\end{array}$ \\
\hline 2 & $\mathrm{~T}_{2}=$ Akola Bahar & $\begin{array}{c}16.75 \\
(24.12)\end{array}$ & $\begin{array}{c}27.81 \\
(31.82)\end{array}$ \\
\hline 3 & $\mathrm{~T}_{3}=$ PhuleUtakarsh & $\begin{array}{c}17.31 \\
(24.58)\end{array}$ & $\begin{array}{l}29.76 \\
(33.02)\end{array}$ \\
\hline 4 & $\mathrm{~T}_{4}=\mathrm{GOA}-5$ & $\begin{array}{l}21.05 \\
(27.28)\end{array}$ & $\begin{array}{l}31.59 \\
(34.14)\end{array}$ \\
\hline 5 & $\mathrm{~T}_{5}=$ ArkaAnamika & $\begin{array}{l}20.26 \\
(26.71)\end{array}$ & $\begin{array}{c}31.01 \\
(33.83)\end{array}$ \\
\hline 6 & $\mathrm{~T}_{6}=$ Punjab Padmini & $\begin{array}{c}24.54 \\
(29.67)\end{array}$ & $\begin{array}{c}29.32 \\
(32.77)\end{array}$ \\
\hline 7 & $\mathrm{~T}_{7}=$ ParbhaniKarnti & $\begin{array}{l}20.90 \\
(27.20)\end{array}$ & $\begin{array}{c}29.43 \\
(32.83)\end{array}$ \\
\hline 8 & $\mathrm{~T}_{8}=$ Akola 107 & $\begin{array}{l}19.96 \\
(26.78)\end{array}$ & $\begin{array}{l}21.29 \\
(27.48)\end{array}$ \\
\hline & Mean & $\begin{array}{l}19.86 \\
(26.44)\end{array}$ & $\begin{array}{c}28.30 \\
(32.09)\end{array}$ \\
\hline & SE & 0.36 & 0.11 \\
\hline & $\mathrm{CD}$ & 1.12 & 0.33 \\
\hline
\end{tabular}




\section{Varietal details}

\begin{tabular}{l|l|}
$\mathbf{T}_{1}=$ VarshaUpahar \\
$\mathrm{T}_{3}=$ PhuleUtakarsh \\
\hline $\mathbf{T}_{5}=$ ArkaAnamika \\
\hline $\mathrm{T}_{7}=$ ParbhaniKarnti
\end{tabular}

Similar results found by Kaur et al., (2013) recorded low mean fruit infestation (18.09$18.68 \%$ and $18.10-19.68 \%$, fruit in number and weight basis, respectively) was observed in Punjab- Padmini and Punjab-8 as against Punjab-7 (22.27 -23.29\% fruit in number and weight basis). Rehman et al., (2015) evaluated seven okra varieties viz., Taj Vendhi, BARI Dharos- 1, ArkaAnamika, Green Finger, Green Soft, OK-285 and Nabik against okra shoot and fruit borer. Among the seven varieties, Taj Vendhi was the most preferable variety as the highest average shoot $(26 \%)$ and fruit (24\%) infestation were recorded. On the contrary, ArkaAnamika was found least preferable variety with lowest shoot $(10 \%)$ and fruit (11\%) infestations. Moderately preferred variety was OK-285, followed by Green Soft and Green Finger. Preference rank for okra shoot and fruit borer among seven okra varieties was Taj Vendhi, OK-285, Green Soft, Green Finger, BARI Dharos-1, Nabik and ArkaAnamika.

The varietal section is the best tactic of integrated pest management system for suppressing pest population below economic injury level. During this field study, among theeight genotypes/varieties of okra, none of the cultivars was found to be free from pest infestation in the year 2016 and 2017. The minimum shoot damage was recorded on variety Akola Bahar (14.87\%), whereas the maximum damage was recorded on Punjab Padmini (25.68\%). The per cent fruit damage revealed that the infestation fruit damage ranged from 26.12 to 33.08 per cent on different genotypes/varieties. The variety Akola Bahar recorded less damage (26.12\%)

\section{$\mathbf{T}_{2}=$ Akola Bahar}

$\mathrm{T}_{4}=$ GOA-5

$\mathrm{T}_{6}=$ Panjab Padmini

$\mathrm{T}_{8}=$ Akola 107

to fruits as compared to rest of the other varieties.

\section{References}

Aziz MA, Hasan M, and Ali A. Impact of abiotic factors on incidence of fruit and shoot damage of spotted bollworms, Earias spp. on okra (Abelmoschus esculentus L.). Pak. J. Zool., 2011; 43: 863-868.

Bangar N, Patel JJ, and Dhruve JJ. Susceptibility against okra shoot and fruit borer, Eariasvittella (Fabricius) (Noctuidae: Lepidoptera) in okra were carried out at Vegetable Research Station Farm, Anand Agricultural University, Anand. Indian $\mathbf{J}$ Agric. Biochem., 2012; 25 (1): 76-79.

Butani DK, and Jotwani MG. Insects in vegetables. Periodical Expert Book Agency. Vivek-Vihar, Delhi (India). 1984; 45-66.

Fletcher TB, and Mishra CS. Cotton boll worms in India. Report, Proc. Entom. Meeting. 1990; 2: 443-472.

Gonde AD, Ashwani Kumar; Raut AH, Wargantiwar RK, and Phuke DP. Screening varieties of okra (Abelmoschus esculentus (L.) Monech) against important insect pest under agro climatic condition of Allahabad (U. P.). Trends in Biosciences, 2012; 5 (3): 249.

KanwarN, and Ameta OP. Assessment of loss caused by insect pests of okra, Abelmoschus esculentus (L.) Moench. Pestology, 2007; 31 (5): 45-47.

Kaur S, Kaur KG, and Singh S. Influence of sowing dates and varieties of okra on 
incidence of shoot and fruit borer, Earias spp. under field conditions in Punjab. Insect Environ. 2013; 19(3): 4549.

Mohan J, Krishnaiah K, and Prasad VG. Chemical Control of Insect Pest of Okra. Indian J. Ent., 1983; 45(2): 252258.

Pareek PL, and Bhargava MC. Estimation of avoidable losses in vegetables caused by borers under semi-arid condition of Rajasthan. Ins. Environ. 2003; 9: 59-60.
Radake SG, and Undirwade RS. Seasonal abundance and insecticidal control of shoot and fruit borer, Earias spp. on okra, Abelmoschus esculentus (L). Ind. J. Ent., 1981; 43: 283-287.

Rahman MA, Uddin MM, Haque MA and Rahman MM. Varietal Preference of okra Shoot and fruit Borer, Earias vittella (Fab.) under field condition in Bangladesh, Academic Res. J. Agri. Sci. and Res., 2015; 3(1): 8-12.

\section{How to cite this article:}

Vinayak N. Jalgaonkar, Manoj Mahla, Kumud Naik, Anil Vyas and Gopal Golvankar. 2018. Varietal Preference of Okra Shoot and Fruit Borer, Earias vittella (Fab.) in Summer Season under Field Condition in Konkan Region of Maharashtra. Int.J.Curr.Microbiol.App.Sci. 7(11): 2397-2402. doi: https://doi.org/10.20546/ijcmas.2018.711.272 